\title{
The reason to stop infliximab is clearly related to the existence of new alternatives: a correspondence analysis of biologics, reasons to stop, and time periods
}

\author{
Julia Uceda ${ }^{1 *}$, Loreto Carmona ${ }^{2}$, Alejandro Muñoz ${ }^{1}$, Jose L Marenco ${ }^{1}$ \\ From 7th European Workshop on Immune-Mediated Inflammatory Diseases \\ Noordwijk aan Zee, the Netherlands. 28-30 November 2012
}

\section{Background}

The reason to stop the first biologic may vary from agent to agent and also from the earlier times to the more recent ones. Issues like the availability of newer alternatives or a better knowledge of the effectiveness and safety profile of individual biologics may influence treatment decisions, including the discontinuation of the biologic.

\section{Objective}

To visually assess the relationship between the reason for stopping the first biologic and the period of time when the biologic was started.

\section{Methods}

All patients with rheumatoid arthritis undergoing treatment with a biologic are registered in the clinical database of a single center with seven treating rheumatologists. The biologic used, as well as the reason to stop it is recorded, as well as all dates regarding the start and the last dose. We performed a multiple correspondence analysis with the Burt method of adjusted inertias and standard normalization with the variables: first biologic, time period (19982001, 2002-2005, 2006-2009), and reason to stop (adverse event, inefficacy, others). Correspondence analysis provides a means of displaying or summarizing a set of data with categorical variables in two-dimensional graphical form.

\section{Results}

The total inertia of the exploratory analysis was 0.10. The first two dimensions added to $57 \%$ of the inertia, so

${ }^{1}$ Rheumatology Dept., Valme University Hospital, Sevilla, Spain Full list of author information is available at the end of the article that all dimensions were accounted for. The major drives of the relationship between the three variables were "infliximab" and the time period "1998-2001" (\% inertia 0.146 and 0.177 , respectively). The distance between other categories of the three variables was not relevant enough to make any suggestions of an association. (See Figure 1).

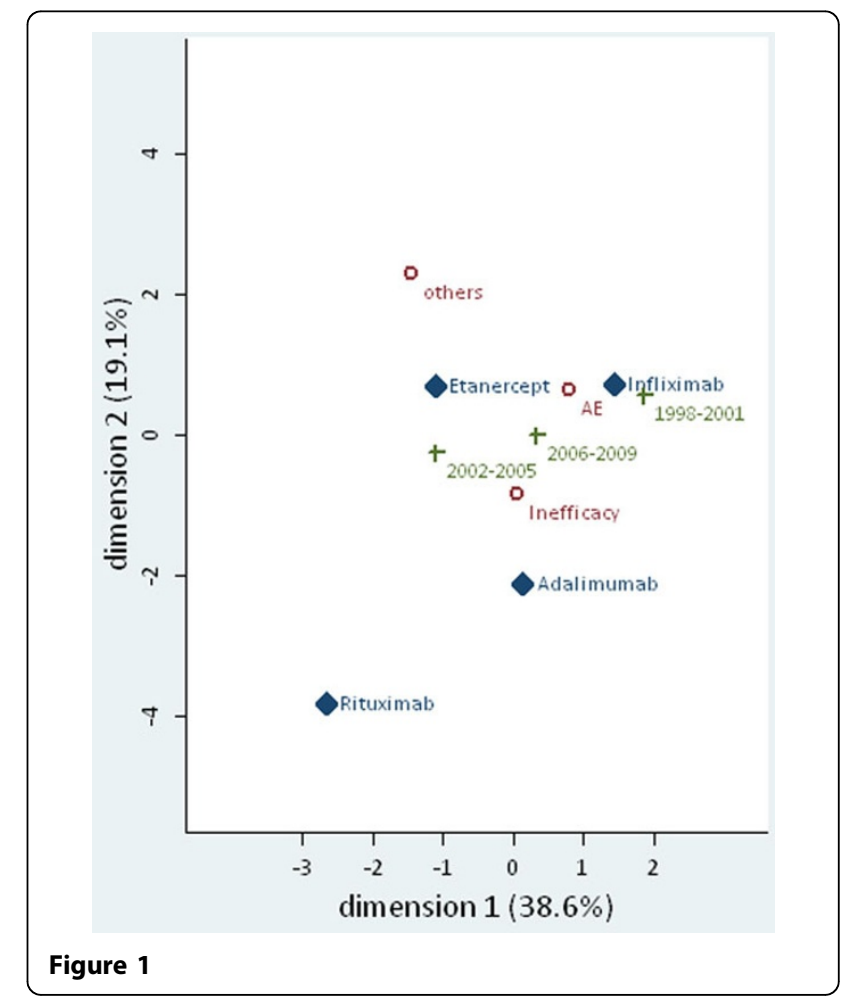

C 2012 Uceda et al; licensee BioMed Central Ltd. This is an Open Access article distributed under the terms of the Creative Commons 


\section{Conclusions}

Time has affected the decision to start infliximab, with more treatments started in the earlier times than in the later ones. The reason to stop any first biologic does not clearly relate to the time neither to the biologic itself in this single center dataset.

\section{Author details}

${ }^{1}$ Rheumatology Dept., Valme University Hospital, Sevilla, Spain. ${ }^{2}$ Camilo José Cela University, Madrid, Spain.

Published: 28 November 2012

doi:10.1186/1479-5876-10-S3-P28

Cite this article as: Uceda et al:: The reason to stop infliximab is clearly related to the existence of new alternatives: a correspondence analysis of biologics, reasons to stop, and time periods. Journal of Translational Medicine 2012 10(Suppl 3):P28.

Submit your next manuscript to BioMed Central and take full advantage of:

- Convenient online submission

- Thorough peer review

- No space constraints or color figure charges

- Immediate publication on acceptance

- Inclusion in PubMed, CAS, Scopus and Google Scholar

- Research which is freely available for redistribution

Submit your manuscript at www.biomedcentral.com/submit 